\title{
Exploring Spelling Errors among College Students
}

\section{Karim Jawhar Karim}

Department of English, College of Basic Education, University of Salahaddin, Erbil, Iraq

Karim2009.ffpd@gmail.com

\section{Salam Nawkhosh Bakir}

Department of English, College of Basic Education, University of Salahaddin, Erbil, Iraq

Salam.bakir@su.edu.krd

\section{ARTICLE INFO}

\section{Article History:}

Received: $11 / 5 / 2020$

Accepted: 7/6/2020

Published: Spring2020

Keywords:errors, spelling, writing system, college student's error in spelling, spelling errors.

\begin{abstract}
This study is entitled exploring Spelling Errors among college students. This research aims at analyzing kinds of errors, shown gender differences in doing spelling errors, find potential reasons behind the spelling errors among the university students and recommend some ways in which spelling can be improved for Central Kurdish EFL learners in addition to being taught more effectively by their teachers. The quantitative method of investigating the spelling errors of fifty central Kurdish learners from the final year of English department at college of basic
\end{abstract}




\section{QALAAI ZANISTSCIENTIFIC JOURNAL}

A Scientific Quarterly Refereed Journal Issued by Lebanese French University - Erbil, Kurdistan, Iraq

Vol. (5), No (2), Spring 2020

ISSN 2518-6566 (Online) - ISSN 2518-6558 (Print)

Doi:

10.25212/lfu.qzj.5.2.32

education - Salahaddin University are being studied by utilizing two tests multiple choice and dictation both genders were participated.

Findings represent that Phonological knowledge of first language of students, differences in writing system between first language and foreign language, Recklessness and lack of knowledge by the students, carelessness and insufficient knowledge about the words they write, lack of knowledge in English writing system, interference of the mother tongue and its spelling rules have been the issues for their errors. Many English words have silent alphabets in their spellings and a lack of knowledge of correct pronunciation of English words are the reasons behind committing spelling errors. Basis on findings it is recommended that the instructors are advised to relate problematic of spelling errors to students' mother language to draw their attention to the fact that there are many differences between both of them in writing system, direction, sound system, number of letters, orthography...etc. 


\section{Introduction}

Dealing with the nature of language may have a role to define spelling because of the features of various writing systems. Spelling refers to "the process of converting oral language to visual form by placing graphic symbols on some writing surface". Hodges (1984, p.2). Moreover, "spelling is the association of alphabetic symbols called grapheme, with speech sounds called phonemes (the smallest sounds in speech)."Montgomery (1997, p.1). In English language there are various graphemes to identify a single phoneme. Whereas, in Kurdish language each grapheme characterizes only one phoneme. Fatah (2010). Then, the current study will investigate the spelling errors of 50 central Kurdish learners at college of basic education, fourth grade of English department - Salahaddin University for the academic year 2018-2019.

The university students at last grade should be proficient in their skills of English language; if they have lack in one of them, this issue (lack in spelling) leads us to investigate it. This research attempts to discover hidden reasons behind the spelling errors, analyze the kinds of errors among the university students for Central Kurdish EFL learners and recommend some ways in which spelling can be reinforced in addition to be taught more effectively by their teachers. To investigate this problem he uses a two tests. Tests will assist the teachers of language to determine the learner's error and arrange required remedial exercises. Darwesh and Al-Jarah (1997).

The study conducted to find the answer for the following questionn: 
1. What are the most frequent spelling errors of Central Kurdish EFL learners at College of Basic Education $4^{\text {th }}$ grade of English Department?

2. What are the statistical differences between the kinds of errors?

3. What possible reasons might be behind those errors?

4. What are the possible solutions, for both of EFL Kurdish learners and teachers?

5. Which one of males or females making more spelling errors? Why?

Exploring in spelling errors are important because dealing with spelling errors will show us the level of proficiency of students in English language skills, if it determines low level of students we should try to find the lacks in learning process with expecting suitable solutions for both of students and teachers.

\subsection{Literature Review}

\subsection{English writing and spelling system}

The English writing system has been recognized as irregular because of its difficulty as to be compared with other alphabetic writing system as Finnish (Treiman, 1993; Fattah, 2010) as he has stated. Then, it has been considered to be a problem for both the L1 and L2 users of English language. Therefore, the researcher has agreed to some extent with Cook's belief $(1997,2004)$ that has identified that the student should know the language, its grammar, morphology and phonology to spell words in English language. Though in some cases of knowing each element of Cook's list may not help a student spell a word in English in a correct way, like the spelling of the word <lieutenant>. 
Nevertheless, it is not regarded to be a matter with English orthography, Taylor (1981) has recommended that each grapheme may not be matched with phonemes or to a single phoneme in English language. For instance, the grapheme <th> symbolizes different phonemes in the words <thistle> and <that>, as / $/ \theta /$ in the former, and / $/$ in the latter. Also, in Montgomery's (1997) words, as he has stated there is a struggle between phonemic and morphemic symbols in English orthography. Besides, Treiman (1993) has discussed that English writing system represents morphological information as well as phonemic one. Even Cook (2004) agrees with Treiman, and has recommended English does not have a simple orthography that the letters can have direct match to the phonemes, silent letters have many roles in the language and spelling is dealt with morphology too. For example, $\langle$ g $\rangle$ does not match to any phoneme in the word $\langle$ sign $\rangle$, but it matches to /g/ in the word $\langle$ signature $\rangle$. Moreover, the third person singular $\langle\mathrm{S}\rangle$ is spelled the same as $\langle\mathrm{S}\rangle$, but it pronounces in a different way in the words $\langle$ walks $\rangle$, $\langle$ hugs $\rangle$ and $<$ catches $>$ as /s/, /z/ and /rz/ respectively.

On the other hand, there has been an opposition to Sampson's explanation, in which it has been claimed that English has a deep orthography. Sampson's point of view might be dealt with the fact that English has many words whose spellings simply have to be memorized because of their rare features, in which Cook (1997, p.474) has called these visual words like 'hiccough' and 'lieutenant'. Thus, Treiman (1993, p.59) has identified that English has one-to-many and many-to-one matching between phonemes and graphemes. But, for instance, $\langle s\rangle$, in the case of third person $\langle\mathrm{S}\rangle$ can be pronounced with different phonemes, and the sound / $\mathrm{f} / \mathrm{can}$ be 
characterized by $\langle f>$ as in 'fail', and $<p h>$ as in 'phone', in which someone may discuss that Treiman has not been recognized by this kind of difficulty yet. He has not approved that English has many-to-many relations between graphemes to phonemes up till now as it is shown in these two above examples.

\subsection{Kurdish writing system}

Kurdish language is one of the West Indo-Iranian languages in the Indo-European family. Shwani (2008, p.48). As in other world languages, there are different varieties of Kurdish language. However, given the socio-political situation of the nation and the region in which they live, the Kurds do not have a common group or a unified form of language, either verbally or in writing form. Different varieties, dialects or accents make it difficult for users to understand the context, even in Kurdish language.

Within Kurdish varieties, there is no single agreement for the development of one common language variety. There are certain political restrictions and issues that have limited the scope of language development among Kurds in all regions. The Northern Kurmanji speaking Kurdish in Turkey, have not been able to develop their language under political circumstances. Whereas, the majority Central (Sorani) speaking Kurdish in Iraq have successfully developed the language skills without political restrictions. Kurds in Iraqi Kurdistan/Krg are able to improve their variety and most of them already started writing their varieties because of political freedom. Nawkhosh (2003) outlined that there are three fundamental systems to Kurdish writing including; Slavic-based writing system by the Kurds of the former 
USSR, Latin-based by the Kurds of Turkey and Syria and an Arabic-based writing system by the Kurds of Iran and Iraq.

In addition to that Nanawazadah (2005), claims that Kurdish has thirty-six letters considering the written language 7 vowels and diphthongs with 29 consonants which corresponding to 36 phonemes. Fatah (2010) illustrate that Kurdish has phonemic writing system in which each grapheme corresponds to one phoneme. There is a one-to-one relationship between letters and graphemes.

\subsection{Central Kurdish variety:}

The Kurdish languages varieties. Khalid (2015). The method of study is content analysis. The researcher highlights that Kurdish being a multi-variety language faces few linguistic challenges. The results of the study indicates the absence of linguistics policies due to lack of unity of Kurds. The researcher performs the linguistic comparison between neighbouring towns of Kurdistan, Iran and Turkey phonetically.

So it is clear that the Kurdish language is an independent language and that it is one of the north-western languages of the Iranian language group which is in its turn one of the greater off-shots of the Indo-Iranian group which has a close relation to the group of European languages. Those languages and groups of languages come under the comprehensive linguistic term Indo-European languages. Fuad $\mathrm{H}$. Khorshid (1983). The Kurdish language is spoken widely all over the south and southeastern parts of Turkey, the northern parts of Syria and north-eastern parts of Iraq as well as west part of Iran except khuzesta (Arabistan), So it spreads over a large 
area of south-western Asia extending north of leninkan (Soviet Union). Fuad H. Khorshid(1983). The Kurdish varieties are divided, according to the linguistic and geographical facts, into four main varieties. They are: Northern Kurmanji, Middle Kurmanji (Central), South Kurmanji and Gurani. Fuad H. Khorshid (1983).

There are three main factors that had had an impressive role in the separation of this language into varieties since early times, they are: the issue of state or nationhood, Geographical and political factors. The central variety is a language spoken in many areas around the world especially in two countries, Iran and Iraq. The variants of Central Kurdish varieyt that today most of them are considered as sub-dialects or sub-varieties of central variety are listed here, (mukriyani, Ardalani, Garmiani, Hawlere, Babani and Jafi).

\section{Methodology}

The study uses a quantitative approach to collect data. The researcher collected the data from a sample of 50 undergraduate students quantitatively through a questionnaire (tests). Quantitative research design includes deductive reasoning to answer the research questions. The hypotheses in quantitative reasoning are formed before they have been tested. These hypotheses are affirmed as the collected data is analyzed.

Hence, a quantitative questionnaire was used to collect data and answer the research questions. 
Questionnaire is a research tool that can be used to gather data from a number of respondents. The questionnaire includes a set of written questions that are designed specifically for certain topics. The researcher distributed 50 questionnaires with English students studying in Salahuddin College of Basic Education in Northern of Iraq/Hawler. Each respondent took about 55 minutes to answer the questions in the given. The questionnaire was obtained back successfully from all respondents.

\subsection{Data Analysis and sampling procedures}

There are four main kinds of language tests, they are prognosis, progress (some time called performative or diagnostic), achievement and proficiency. For the current study, the achievement test has been conducted. An achievement test is the most suitable kind to follow as far as the aims and procedure of the work require. An achievement test completely suitable and flexible when the tester intends to measure students' mastery over a specific aspect of language which has been taught and studied for a long time Smedley (1983). Furthermore, English spelling test is the famous suitable tools for data collection. The test form is classified into two discrete divisions. The first division is of recognition kind and the second of production as stated and explained in Omar (2017). in which the recognition test tests students competence for recognizing right and suitable answers, by the contrast, production test aims at assessing student's ability to invest and produce answers by themselves.

A total of fifty EFL undergraduate students were taken as a sample of the study. The participants of the study were selected from 4th year English department in Salahaddin university College of Basic Education. The sample size was determined 
Vol. (5), No (2), Spring 2020

ISSN 2518-6566 (Online) - ISSN 2518-6558 (Print)

using convenient sampling. Etikan, Musa and Alkassim (2016) defined convenient sampling as non-probability sampling design that allows selecting the sample from a particular part of population that is close to hand. Ferrokhi and Mahmoudi (2012) also argued that convenient sampling is better than random sampling for selecting the participants. Out of 50 participants that took part in the study, $62 \%$ were females and $38 \%$ were males. This also implies that there are more female students in English department than male students (see Table 1).

Table 1

Participants of the study

\section{Variable}

$$
\text { Description }
$$

Responses

Percentage

\section{Gender}

$$
\text { Female }
$$

31

$62.00 \%$

Male

$38.00 \%$

Total

50

$100 \%$

\subsection{Test 1 (multiple-choice)}

Test 1 was a specifically designed for this study. Multiple-choice questions were asked in the test. The participants were given a list of 25 words. Words were read with English in their native English at eight-second intervals between each word. Each word was read twice at 4 seconds intervals. Omar (2010) conducted a similar study 
for time intervals based on a similar type of test. Participants were asked to choose the correct spelling of the word among the three options. Most options were not, or very similar to, words in the English language. Nonetheless, there was only single correct spelling for each item in the test. Alderson et al. (1995) argued that this is one of the basic requirements of a multiple-choice test.

Brown (2004, p.28) says that the practical application and reliability of multiple choice tests is very high. It is practical because it is easy to build, and reliable because the scores are very objective, given that the answer can be right or wrong. Alderson et al. (1995, pp.9-16) agree with Brown and state multiple choice tests are the most objective. Alderson et al. (1995, p.16) Note that having four alternative responses in multiple choice elements is good because it reduces the chance of appreciation by $25 \%$. They also argue that the correct answer should not resemble deviations. Therefore, operators have been carefully expressed that they have different sound clips, not words with the same pronunciation, to any homogeneous speaker. Brown (2004) also mentioned that multiple choice elements only examine students' knowledge of recognition. This corresponds to the purpose of Test 1 to assess student recognition performance in recognizing the correct spelling of words. Test 1 improves the reliability of Test 2 and allows the researcher to determine whether participants, in case of a misspelling, can rely on the way they speak of letters under the influence of L1 writing systems. It has a direct correspondence between graphics and acoustics.

\subsection{Test 2 (dictation)}


Test 2 is a spelling test specifically designed for this study by the researcher. A similar approach is followed for test 1 . However, there are 25 words, no specific options, and each lab has ten seconds to write each word read twice (every five seconds). Spelling test according to (Gall et al., 2007) was conducted. In addition, Baker (1989) argues that students should understand words in spelling tests. You should not dictate unknown words. For practical reasons, Alderson et al. (1995) stated that it is better to have materials on the tape when using spelling tests. All this justifies why the words were pre-recorded and not read by the invaders during the test in this study.

\subsection{Ethical Consideration}

Ethics is the most susceptible subject matter that must be addressed in any research. During research, researchers are in power and should not abuse this power (Gall et al. 2007). Punch (2005) states that informed consent, project value and research benefits are all ethical issues to consider. Punch (2005) argues that the study predicts relevant ethical problems and then finds solutions. In this study, a consent form translated into Kurdish was used to ensure that there was no misunderstanding about the research and its objectives.

The researcher was directed to the teachers and the principals of the college. The consent forms contain as much information about the study, including the basic goals and methods of data collection. Teachers and principals were told that the identity of the learners will remain anonymous and can be withdrawn at any time without any justification. 


\subsection{Findings and Discussion}

\subsection{Results of Test 1}

In the test 1, the researcher required from respondents of the study to choose the words as they see to answer the question correctly. This was a multiple choice questions exam that the researcher employed to analyze the ability of the respondents in spelling and to analyze their errors. The researcher categorized the errors into seven categories after marking the test. The categories were defined as; (1) substitution, (2) omission, (3) insertion, (4) transposition, (5) mixed-category, (6) invalid and (7) unanswered. 


\section{QALAAI ZANISTSCIENTIFIC JOURNAL}

A Scientific Quarterly Refereed Journal Issued by Lebanese French University - Erbil, Kurdistan, Iraq

Vol. (5), No (2), Spring 2020

ISSN 2518-6566 (Online) - ISSN 2518-6558 (Print)

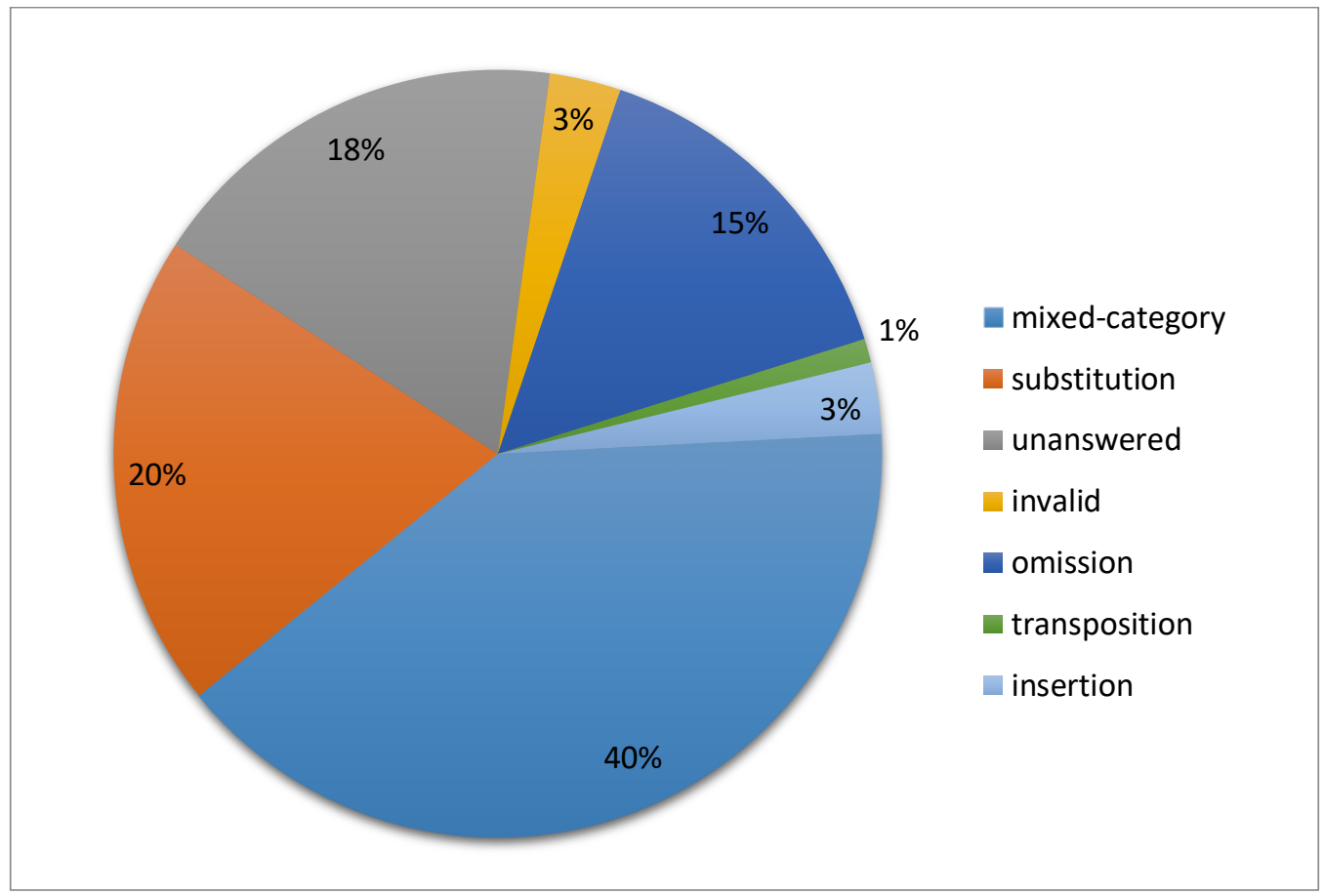

Figure 1: Test I-Spelling Errors

The researcher investigates the ability of Kurdish EFL learners to recognize the correct spellings of the English words. The results of the outline that $40 \%$ of the respondents were mixed-category. For instance, the students chose non-word as $<$ retrevale $>$ for $<$ retrieval>, $20 \%$ were substitution errors, for instance, $<$ critisism $>$ for $<$ criticism $>$. $18 \%$ were unanswered, in which they were not answered to the questions. $3 \%$ were invalid, $15 \%$ were omission, for instance, <acheved> for <achieved>. $1 \%$ was transposition, for instance, <retreival> for <retrieval> and 3\% were insertion errors, for instance, $<$ whole $>$ for $<$ hole $>$. The results of the test 1 are shown in Figure 1 above. 


\section{QALAAI ZANISTSCIENTIFIC JOURNAL}

A Scientific Quarterly Refereed Journal Issued by Lebanese French University - Erbil, Kurdistan, Iraq

Vol. (5), No (2), Spring 2020

ISSN 2518-6566 (Online) - ISSN 2518-6558 (Print)

\subsection{Results of Test 2}

Following test 1 , test 2 was a dictation and it was designed to test the ability of students to write down the spellings of English words as they hear them. The researcher categorized the responses of participants in the above described seven categories. The results of test 2 are shown in Figure 2 below.

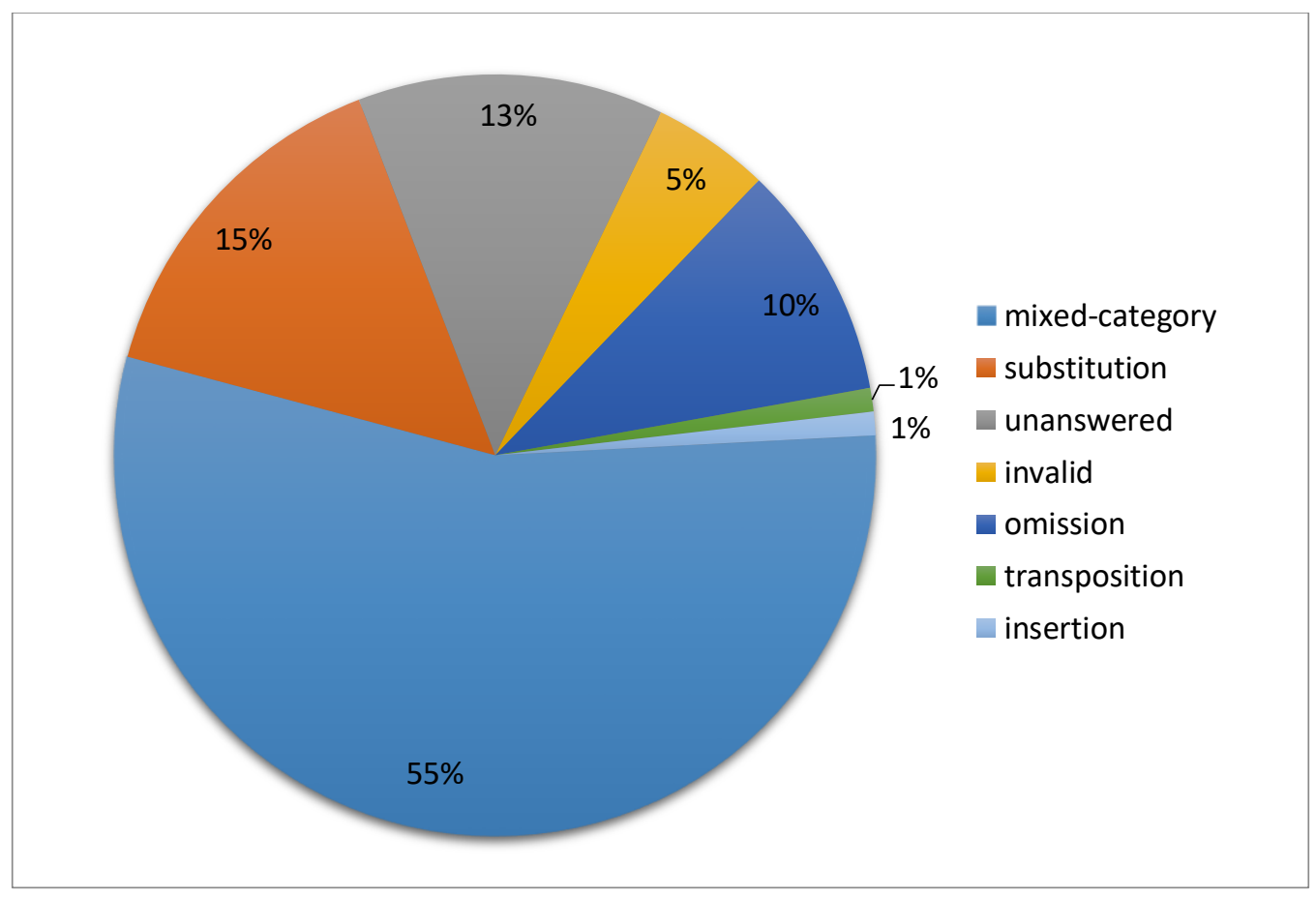

Figure 2: Test II-Dictation

The researcher tested the ability of Kurdish EFL learners to produce the words of English as they hear them. The results of study outlined that $55 \%$ respondents were mixed-category, for instance, <atmusfer> for <atmosphere>. 15\% were substitution, 
for instance, <rashial> for <racial> $13 \%$ were unanswered, $5 \%$ were invalid, for instance, <conshns> for <conscious>. $10 \%$ were omission, for instance, <seiz> for $<$ seize>. And finally $1 \%$ was transposition category errors, for instance, <anxeity> for <anxiety>.

\subsection{Comparing both tests}

Test 1 is recognition and Test 2 was to test the ability to produce the words. The findings of the study outlines that the ability of central Kurdish EFL learners to recognize and produce English words is different. This is shown in above figures as the percentage of same error categories changed for recognizing and producing words. The percentage for substitution is observed to be higher in both test among other categories but it is highest in recognition test 1 . The total number of errors marked in Test 1 was observed to be 1850 while, there were 2457 errors marked in Test 2 . The researcher find that however, mixed-category errors were observed to be the highest in both tests. 20\% errors are marked as unanswered category in Test 1 that decreased to $13 \%$ in Test $2.3 \%$ errors were marked as invalid in Test 1 that increased to $5 \%$ in Test 2 . Omission errors were observed to be $15 \%$ in Test 1 that decreased to $10 \%$. Transposition errors remained constant as $1 \%$ in both tests. Insertion error was observed to be 3\% in Test 1 that decreased to 1\% in Test 2.

The researcher also analyzed the responses of central Kurdish EFL learners using SPSS and performed t-tests to compare the results between the two tests. The researcher conducted the t-test to observe the variance between the responses of 
participants in both tests. The correlation analysis was also conducted to mark the relationship between the responses.

\subsection{Mixed-Category Spelling Errors}

The results of Test 1 and Test 2 outlined that the central Kurdish EFL learners had high ratio for mixed-category errors than any other type of error as described in the preceding chapters. Mixed-category errors are defined as the errors that have more than one type of spelling errors. Basically, the mixed-category as the name describes is the combination of different types of errors that were observed from the test results. In both Tests, the respondents were observed to have high number of mixedcategory errors. Hence, it is observed that $45 \%$ of errors were mixed-category errors that have been studied before by Jiang (2010) that observed that spelling errors among second language students. However, the percentage of mixed-category errors observed in the present study is higher. The study also suggested that most mixedcategory errors are combination of omission and substitution. These results are consistent with the current study that substitution and omission errors were followed by mixed-category. The phoneme $/ \Theta /$ does not exist in Kurdish language; therefore, one might argue that it is quite logical for a central Kurd EFL learner to confuse the phoneme $/ \Theta /$ with $/ \mathrm{f} /$ and respectively change the grapheme $\langle\mathrm{th}>$ to $\langle\mathrm{f}\rangle$ due to $\mathrm{L} 1$ interference. This is consistent with what Cook (1997) discovered about SL users of English from different first language (L1) backgrounds.

In comparison, percentage of insertion in spellings with mixed-category errors is observed to be only $4 \%$. This means that only few words were found to be with 
insertion error in the mixed-category. Al-Jarf (2009) outlined that EFL students make insertion errors due to the influence of their first language. They make errors in hearing the words and due to the phoneme problem, some errors cannot be avoided.

In summary, the Kurdish language is a phonemic language, then mostly the students of this language will follow the same method when they spell English words as well.

\subsection{Substitution}

Substitution errors are observed to be the second highest among central Kurdish EFL learners. The respondents in both Test 1 and Test 2 made the second highest substitution errors. The analysis of the findings suggests that the substitution error is due to the confusion between the vowels and consonants, for instance <critisism $>$ for $<$ criticism>. The respondents of the study made consonants and vowel errors equally under the substitution errors.

\subsubsection{Consonant Substitution}

The substitution of consonant suggests that $55 \%$ of the substitution errors were made under consonants. The results suggest that substitutions were commonly made with $\langle\mathrm{th}\rangle$ to $\langle\mathrm{f}\rangle,\langle\mathrm{v}\rangle$ to $\langle\mathrm{f}\rangle,\langle\mathrm{c}\rangle$ to $\langle\mathrm{k}\rangle$ in Test 1 , for instance, $\langle$ auforities $>$ for <authorities>, <achiefed> for <achieved> and <okcasion> for <occasion>. However, the number of consonants under substitution errors as compared to vowel substitution errors was observed to be fewer in Test 2 . Thus, consonant substitution 
error examples are traceable to different sources: either $L 1$, overgeneralization or carelessness of the respondents and tendency of Kurdish EFL learners only to write the obvious sounds in the words, the stressed ones, and miss those which are not stressed.

\subsubsection{Vowel substitution}

The substitution of vowels in Test 1 and Test 2 was $45 \%$ of the errors in the category. However, the percentage varied across the two tests. In Test 2 vowel substitution was higher as compared to Test 1 . The vowel errors are observed to be

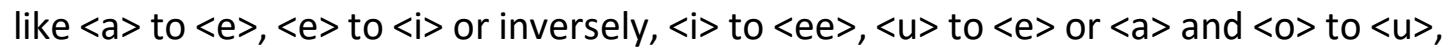
For instance, <citetions $>$ for $<$ citations $>$, <atmosphire $>$ for $<$ atmosphere $>$, <raceeal $>$ for $\langle$ racial $>$, <pebescent $>$, for $<$ pubescent $>$. And $<$ cumb $>$ for $<$ comb $>$.

Moreover, Cook (1997) outlined that vowel substitutions are a problem not for merely L2 users of English but L1 users of the language as well.

\subsection{Omission}

Omission is also observed to be relatively high in the category. The results of the study suggest that there are four main types of omissions observed in the spelling errors made by Kurdish EFL learners. The four main types are observed to be; (1) omitting a letter which is a part of the word without substituting it with another letter 
(either vowel or consonant), (2) omitting silent letter or letters in a word, (3) omitting a letter or letters in the end of the words, (4) omitting a letter when two are required and omitting.

\subsubsection{Single Letter Omissions}

The single letter omission refers to the omission of a letter in the word without substituting the word with another letter. This is found for both vowels and consonants. The results found that omissions are made in the middle of the words rather than in the beginning. No vowel or consonant omissions are observed in the beginning of the words, for instance, <retrival> for <retrieval>, <ocasion> for <occasion> and <seze> for <seize >. Therefore, only one grapheme is written and the other is omitted which is a typical approach for spelling in Kurdish language.

\subsubsection{Silent Letter omissions}

Silent letters in words are usually omitted in both tests. The results of the study are consistent with the findings of Cook (2004) that argued about the omission of $\langle\mathrm{h}\rangle$, \langle|$>,\langle\mid\rangle,\langle\mathrm{h}\rangle$ in the second language students, for instance, <wak $>$ for $\langle$ walk $\rangle$, $<$ psycologist $>$ for $<$ psychologist $>$ and $<$ bam $>$ for $<$ balm $>$.

\subsubsection{Omission in double letters}


Approximately, $50 \%$ of omission errors are observed for letters that required double consonants. Therefore, the findings suggest that when consonants are doubled in Kurdish language, Kurdish EFL learners also double the phoneme by extension, for instance, <permision $>$ for $<$ permission $>$, <ocasion $>$ for $<$ occasion $>$ and <inteligibility> for <intelligibility>.

\subsubsection{Omitting letters at the end of Words}

The results of the study found that the omission of letters is common in both Test 1 and Test 2 among Kurdish EFL learners. The researcher found that in most cases <e> is omitted including <atmospher> for <atmosphere>, <unconscionabl> for < unconscionable> and <seiz> for <seize>. Cook (1997) and Omar (2010) argued that these omissions are common in English and Arabic language as they observed for Libyan EFL students. The results of the study are consistent with these studies and the problem of Central Kurdish EFL learners is similar to those of these studies. Second language students' pronunciation of a specific word might have considerable effect on whether or not they omit graphemes.

\subsection{Insertion, Transposition, invalid}

The results of the study suggest that Kurdish EFL learners made more errors in Test 2 as compared to Test 1 . The Kurdish EFL learners are better in recognizing a word than producing the words. Number of invalid items was higher in Test 2 as compared to Test 1 . The number of insertion and transposition is very low as compared to other 
error categories. There are fewer examples of letter insertion compared to transposition , for example <opportunnity> for <opportunity>, <acquiesition> for <acquisition>, <anxeity> for <anxiety> and <dyscyplyny>, for <discipline>. The number of each category is not high. Errors of insertion only accounted for $1 \%$ of the total number of errors in Test 2 and $0 \%$ of the total number of errors in both tests. The reason for these errors, as stated previously, might be ignorance or not knowing the rules of English orthography.

\section{Comparison male with female errors}

The results of the study outlines that males as compared to females made more spelling errors. This is may be because of the academic culture among central Kurdish EFL learners. Females were more into language learning as compared to males. The results of the study totally agree with Michael (2012) who determined that the female mostly better than male in both of aspects of language and communication. It means that there are faster process of working and transporting the signals at female's brain compared male's one. Domnic (2011).

Furthermore, there are big differences between the genders in storing language and personal memories, the temporal and frontal area of cortex accurately arranged in female's brain and bigger in volume compared to male's brain this may assert of expanding specialization of the temporal cortex for language processing in females, and this one also related to conducting better performance of language by the female, and The two areas of brain linked with language harder in the female than 
male since the language tasks Domnic (2011). Then, we can say that the female's brain is more proficient in the vocabulary by using both sides of brain in production of language. This one also similar to the results of current study which predict that the females are more accurate and clever that males.

Finally, female are better in male in language and better in recall list of words or paragraphs of text than male Domnic (2011). Similarly It represents that females are more accurate and clever than males.

\section{Conclusions}

Depend on analyzed data, the following conclusions are drawn:

We could be able to see that an omission has a highest rate or score of errors. While the results of analyzed data confirmed that mixed-category has the highest rate or score of errors between whole sorts of errors which (\%40) in test one (multiplechoice) and (\%55) in test two (dictation).

Based on analyzed data the rate Mixed-category are observed to be the highest in both tests. 20\% errors are marked as unanswered category in Test 1 that decreased to $13 \%$ in Test $2.3 \%$ errors are marked as invalid in Test1 that increased to $5 \%$ in Test 2. Omission errors were observed to be $15 \%$ in Test 1 that decreased to $10 \%$. Transposition errors remain constant as $1 \%$ in both tests. Insertion error is observed to be $3 \%$ in Test 1 that decreased to $1 \%$ in Test 2.

There are many causes of spelling errors by Kurdish EFL students as described in below: 
Vol. (5), No (2), Spring 2020

ISSN 2518-6566 (Online) - ISSN 2518-6558 (Print)

- Lack of phonological, morphological and orthographical in English language.

- having extra letters in English words for instance, <psychologist $>$. Or silent letters as in, <walk>. In addition to mispronunciation letters as in, <right $>$.

- Carelessness and insufficient knowledge about the words they write

- Lack of knowledge in English writing system and irregularity of English writing system.

- Interference of the mother tongue and its spelling rules

- Inconsistences in English language will require the students of (L2) to memorize many words.

- Various letters may represent one phoneme for instance, <too, too, two >.

- Many English words have silent alphabets in their spellings which also created problem for the students.

- Lack of knowledge of correct pronunciation of English words added to the spelling error

- Lack of correspondence between grapheme and phoneme or sound and spell in English language.

- English language has a deep, irregular and complex orthographic system. 
- several letters in English language as, $\langle\mathrm{x}\rangle,\langle\mathrm{q}>$ and $\langle\mathrm{c}\rangle$ has no any particular sound but they take other sounds like, $\langle\mathrm{e} k \mathrm{~s}\rangle,\langle\mathrm{k}\rangle$, and $\langle\mathrm{s}\rangle$.

- knowing range of rules of English spelling does not have any role to better spelling because of complexity of English spelling system.

- Several sound which exist in English language but not exist in Kurdish language or else.

- The correspondence sound-letter in English language is not regular totally.

- The number of sounds in English language is more than the letters in Kurdish language, but the latter has fewer problematic in this.

- Teachers' inability to improve and arrange suitable spelling activities.

4. there are other suggestions were proposed to improve the spelling performance of Kurdish students as a foreign language: for example, teaching reading and writing as well as spelling, highlighting student errors and practicing vocabulary students tend to spell it wrong. writing is related to pronunciation and reading. For this reason, the researcher has offered teaching of pronunciation and reading comprehension as well as teaching specific writing rules related to speaking and reading lessons. English teachers emphasize the specific spelling errors made by English teachers as a foreign language rather than the general spelling rules. Teach students to focus on silent letters in English language. Frequent uses of personal dictionary by the students. 
5. It is hypothesized that males making spelling errors more than females. Based on analyzed data it is proved. This is may be because of the academic culture among Kurdish EFL students. Females were more into language learning as compared to males. In addition to:

- female are better in male in language and better in recall list of words or paragraphs of text than male, also females are more accurate and clever than males.

6. Spelling errors is one of the pervasive issues which face the central Kurdish students at university.

7. Depend on analyzed data, the current study confirm that $\% 55$ of the substitution errors were made under consonants. Also it was suggest that the substitution of vowel $<\mathrm{i}>$ to $<\mathrm{e}>$ phoneme was a problem with the second language students.

8. The results of both of the tests outlined that the performance and ability of central Kurd EFL learners much higher for recognizing than for producing (writing) English words.

\section{Suggestion for further studies}

Depend on the findings of current study, the following are suggested for further studies:

- A similar research could be done on spelling errors but on northern variety of Kurdish language in Turkey.

- A similar study could be done on other skills as writing and speaking errors in English language. 
- A similar research could be done by increasing another tool with participating the instructors in interview tool.

- A similar study could be done by increasing other categories of errors, such as capital letters, space, disordering, compounding, contraction and malformation.

- A similar study could be done by utilize many American and British words which are differ in spelling.

\section{References}

Abu-Rabia, S., and Taha, H. (2006). "Phonological errors predominate in Arabic spelling across grades 1-9". Journal of Psycholinguistic Research, 35 (2), pp. 167-188.

Alderson, J. C., Clapham, C., and Wall, D. (1995). Language test construction and evaluation. Cambridge University Press.

Al-Jarf, R. (2009). "Phonological and orthographic problems in EFL college spellers". Paper presented at TELLIS Conference Proceedings. Azad Islamic UniversityRoudehen, Iran, 28/04/2009. Available at http://repository.ksu.edu.sa/jspui/bitstream/123456789/5618/1/Phonolog ical\%20

and\%200rthographic\%20Problems\%20in\%20EFL\%20College\%20Spellers.p df [Last accessed: 20-07-2014]

Brown, H. D. (2004). Language assessment: Principles and classroom practices. New York: Pearson Education.

Carney, E. (1994). A survey of English spelling. Routledge. 
Cook, V.J. (1997). "L2 Users and English Spelling". Journal of Multilingual and Multicultural Development, 18, (6), pp. 474-488.

Cook, V.J. (2004). The English writing system. London: Arnold.

Darwesh, A.J. \& Faris Al-Jarah (1997). An elementary course in testing English as a foreign language for student teachers. Baghdad: Al-Safadi publications.

Domnic, M. (2011). Biological difference between male and female brain. Kampala international university.

Etikan, I., Musa, S. A., \&Alkassim, R. S. (2016).Comparison of convenience sampling and purposive sampling.American journal of theoretical and applied statistics, 5(1), 1-4.

Farrokhi, F., \&Mahmoudi-Hamidabad, A. (2012). Rethinking Convenience Sampling: Defining Quality Criteria.Theory \& Practice in Language Studies, 2(4).

Fatah, M. M. (2010). "A Phonetic Perspective to Kurdish Orthography". In: Khoshnaw, Sh. H. and Qadir, Sh. M. (eds.). Linguistic Investigations (in Kurdish) (pp.41-70). Iraq: Mukiryani Publishing House.

Fuad H. Khorshid. (1983). Kurdish language and geographical distribution of its dialects. Baghdad- Ishbelia press.(pp. 9-28).

Gall, M. D., Gall J. P. and Borg, W. R. (2007). Educational Research: an Introduction (8th ed.). Pearson Education: USA.

Habib, B. A. (2004). Unified Kurdish Orthography (in Kurdish). Iraqi-Kurdistan: Erbil Publishing House.

Hodges, R. E. (1984). "Spelling". ERIC Clearinghouse. Available at http://files.eric.ed.gov/fulltext/ED250695.pdf [Accessed 15-07-2014]

Jiang, X. (2010). Analysing spelling mistakes of China Vocational College EFL 
Learners. Unpublished MA dissertation. Newcastle University.

Khalid, H. S. (2015). Kurdish Dialect Continuum, as a Standardization Solution. International Journal of Kurdish Studies, 1(1), 27-39.

Matras, Y., and Reershemius, G. (1991). "Standardization beyond the state: the cases of Yiddish, Kurdish and Romani". In: Gleich, U. V. and Wolff, E. (eds.). STANDARDIZATION OF NATIONAL LANGUAGES. Hamburg: Unesco Institute for Education (UIE) and Graduiertenkolleg Mehrsprachigkeit und Sprachkontakte. pp. 103-123.

Michael, S. (2012). Male and Female Brain Differences. Valdosta state university. Mark C Farthing ACED 7150

Montgomery, D. (1997). Spelling. London: Biddles Limited.

Nanawazadah, A. (2005). Herman Kurdish Dictionary (in Kurdish). Iraqi-Kurdistan: the Publishing house of Ministry of Education

Nawkhosh, S. (2003). The New Dictionary of Oxford (in Kurdish). Erbil: Roshnbiri Publishing house.

OMAR, J. A. (2017). Kurdish Efl Learners' Spelling Error Types and Sources. Proceedings of Academicsera International Conference, (pp. 1-5). Milan.

Punch, K. F. (2005). Introduction to Social Research: Quantitative and Qualitative Approaches. ( ${ }^{\text {nd }}$ ed) Sage Publications: London.

Saeed Omar, H. A. (2010). Postgraduate Libyan learners' spelling errors, types, and reason behind them. Unpublished MA dissertation. Newcastle University.

Shockey, L. (2003). Sound patterns of spoken English. John Wiley \& Sons.

Shwani, R. (2008). Kurdish Language and its Place among the Languages of the World (in Kurdish). Iraqi-Kurdistan: Khani Publishing House. 


\section{QALAAI ZANISTSCIENTIFIC JOURNAL}

A Scientific Quarterly Refereed Journal Issued by Lebanese French University - Erbil, Kurdistan, Iraq

Vol. (5), No (2), Spring 2020

ISSN 2518-6566 (Online) - ISSN 2518-6558 (Print)

Smedley, D. (1983). Teaching the basic skills: Spelling, punctuation and grammar in secondary English. London: Methuen.

Taylor, D. S. (1981). "English Spelling: A Help Rather than Hindrance". English Language Teaching Journal, 35(3), pp.316-321.

Treiman, R. (1993). Beginning to spell: $A$ study of first-grade children. Oxford University Press.

\section{يـوختـه:}

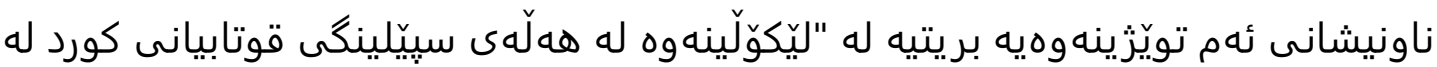

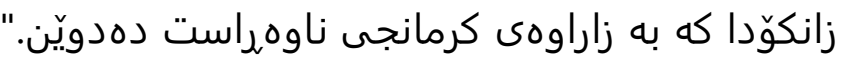

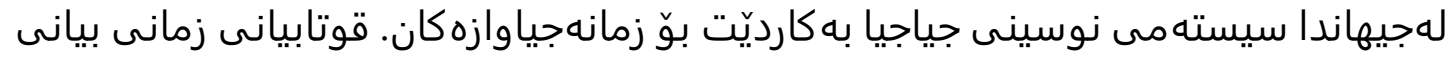

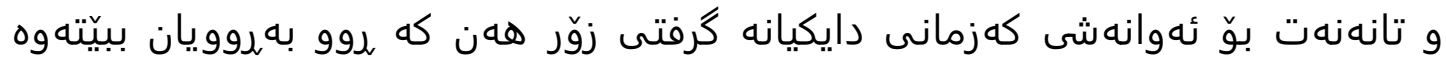

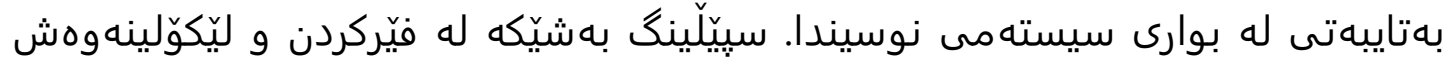

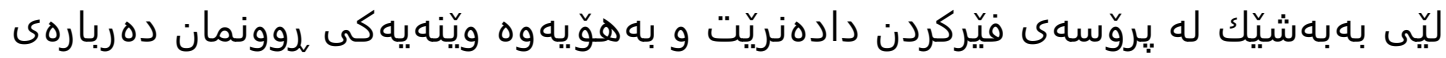

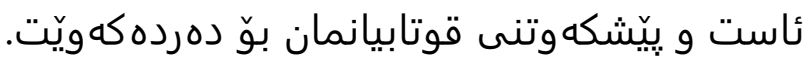

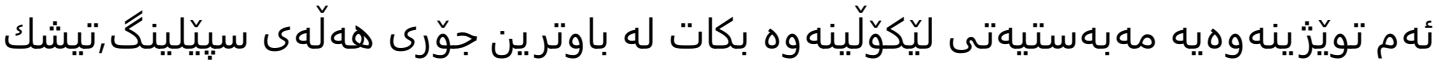

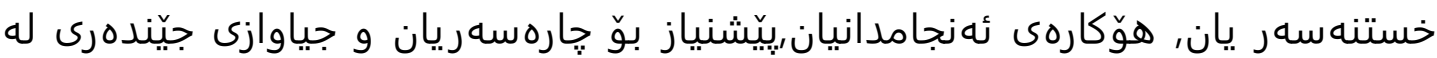
ئه نجامدانيان.

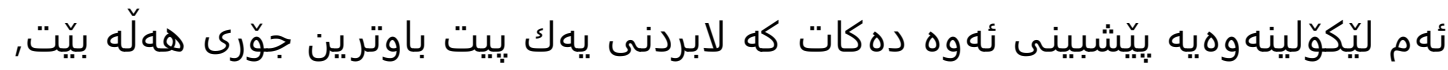

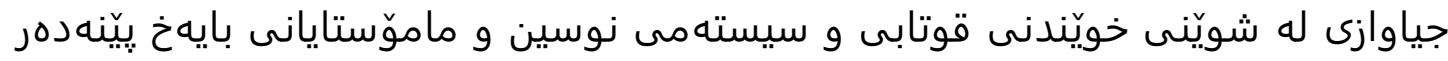

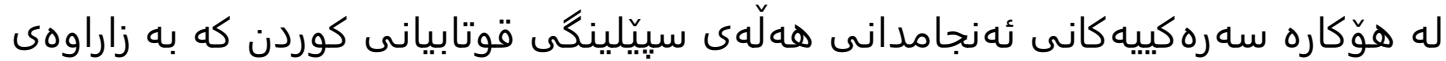

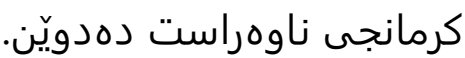

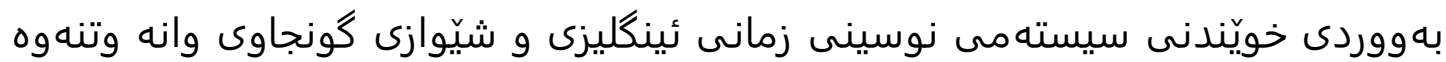

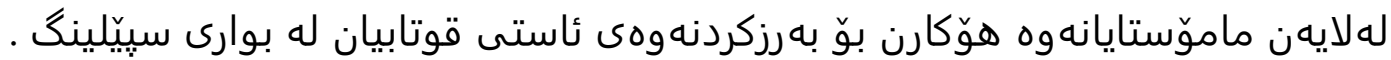

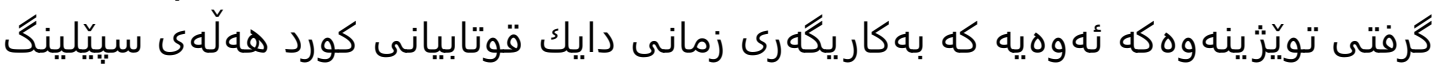

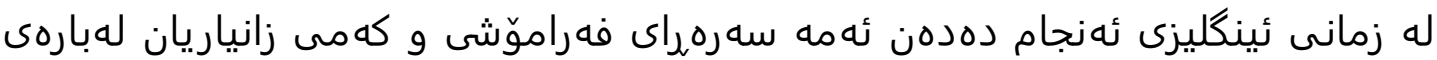
سيستهمى نوسينى زمانى ئينكليزى. 


\section{QALAAI ZANISTSCIENTIFIC JOURNAL}

A Scientific Quarterly Refereed Journal Issued by Lebanese French University - Erbil, Kurdistan, Iraq

Vol. (5), No (2), Spring 2020

ISSN 2518-6566 (Online) - ISSN 2518-6558 (Print)

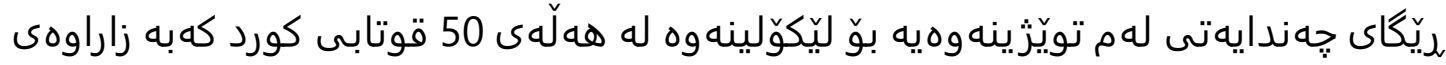

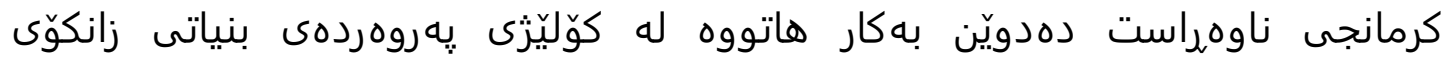

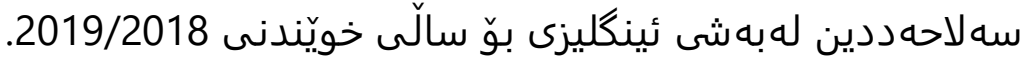

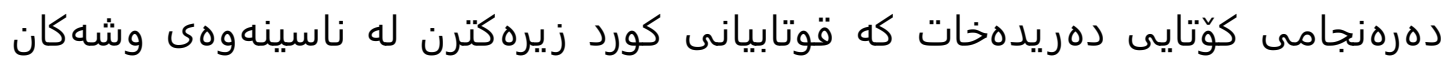

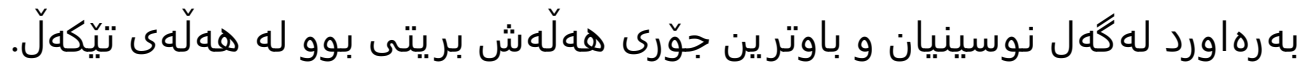

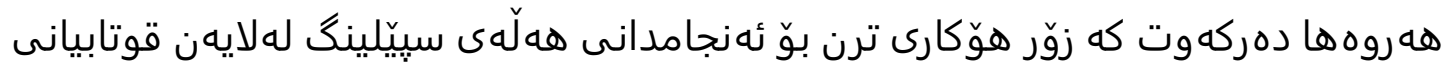

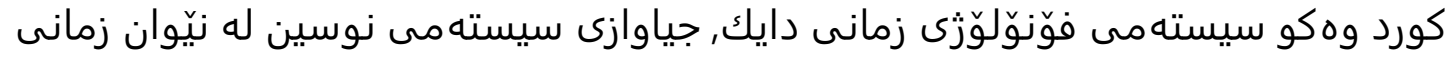

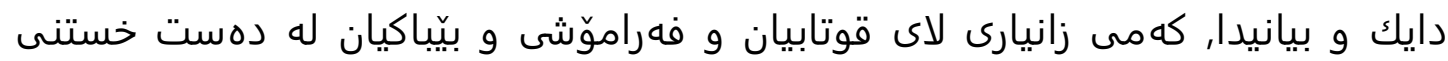

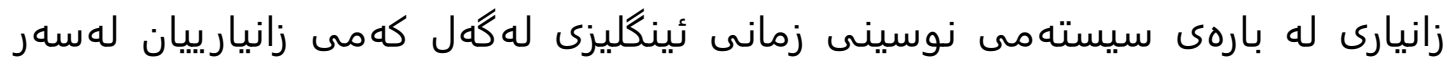
سيستهمى دهنكى زمانى ئينكليزى.

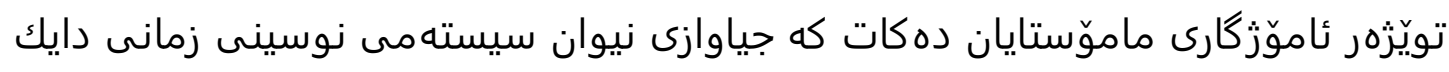

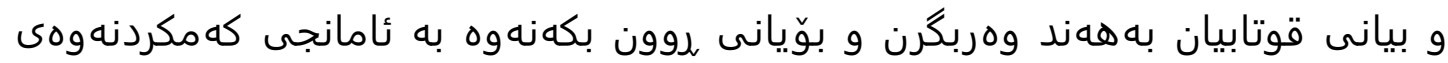
ههلّهى سييّلينگ

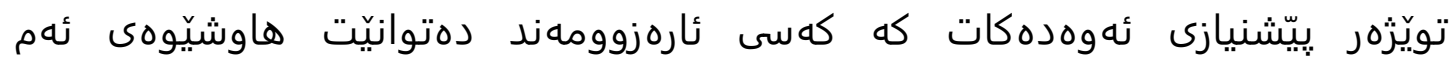

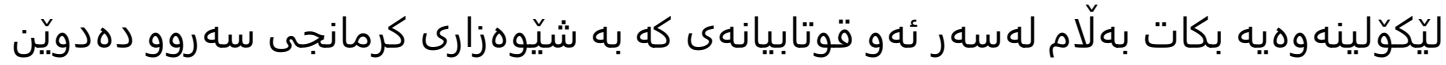
بهتايبهتى له كوردستانى توركيا.

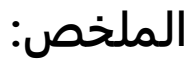

هذه الدراسة بعنوان "استكشاف الأخطاء الإملائية بين طلاب الجامعات". يهدف هذا البحث إلى تحليل أنواع الأخطاء ، وإظهار الفروقات بين الجنسين في القيام بالأخطاء الإملائية ، وإيجاد الأسباب المحتملة وراء الأخطاء الإملائية بين طلاب الجامعة والتوصية ببعض الطرق التي يمكن بها تحسين الإملاء لمتعلمي اللغة الإنجليزية كلغة أجنبية بالإضافة إلى أن يتم تدريسهم بشكل أكثر فعالية من قبل مدرسهم. الطريقة الكمية للتحقيق في الأخطاء الإملائية لـ 50 متعلم كردي (لهجه كرمانجى وسط) من السنة الأخيرة 


\section{QALAAI ZANISTSCIENTIFIC JOURNAL}

A Scientific Quarterly Refereed Journal Issued by Lebanese French University - Erbil, Kurdistan, Iraq

Vol. (5), No (2), Spring 2020

ISSN 2518-6566 (Online) - ISSN 2518-6558 (Print)

في قسم اللغة الإنجليزية في كلية تربية الاساس-قسم اللغة الانجليزية - جامعة صلاح الدين تتم دراستها من خلال استخدام اختبارين الاختيار من متعدد والإملاء وقد شارك كلا الجنسين.

تمثل النتائج أن المعرفة الصوتية للغة الأولى للطلاب ، والاختلافات في نظام الكتابة بين

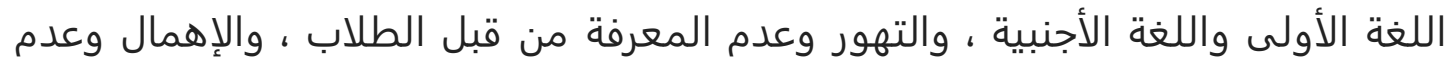
كفاية المعرفة حول الكلمات التي يكتبونها ، ونقص المعرفة في نظام الكتابة باللغة

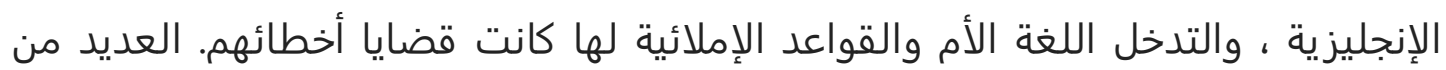
الكلمات الإنجليزية لها حروف أبجدية صامتة في هجاءها وعدم وجود المعرفة الصحيحة للنطق من الكلمات الإنجليزية هي أكثر أسباب الأخطاء الإملائية. استنادًا إلى نتائج

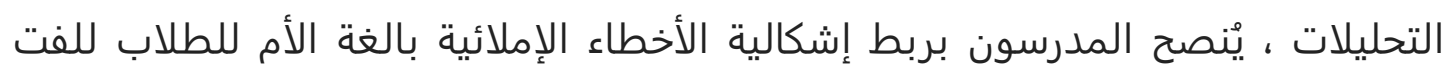

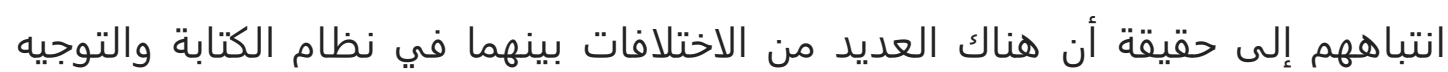
ونظام الصوت وعدد الحروف ، الإملاء. 